\title{
Seed rain and advanced regeneration in a tropical rain forest
}

\author{
M. Martínez-Ramos ${ }^{1} \&$ A. Soto-Castro \\ Centro de Ecología, Universidad National Autónoma de México, Ap. Post. 70-275, México, \\ D.F. 04510, México
}

Keywords: Tropical rain forest, Seed dispersal, Advanced regeneration, Seed and seedling ecology

\begin{abstract}
By comparing seed rain, seedling and sapling community structures we assessed the possible role played by vertebrate seed dispersal as a structuring factor in advanced regeneration of closed-canopied sites in the tropical rain forest of Los Tuxtlas, Mexico. Seed weight, initial morphology of seedlings and species abundance were also analyzed to determine if these traits influenced the probability of establishment in the shade.

About half of the seed species falling in five closed forest sites $(25 \times 25 \mathrm{~m})$ during one year came from fruiting trees growing within the sites (local seeds) and half from fruiting trees found outside the sites (immigrant seeds). Seeds of liana and upper-canopy species were over-represented among immigrant seeds compared with seeds of understory tree species. This probably reflects the activity of frugivorous arboreal mammals, bats, and birds. Species with immigrant seeds had both a lower abundance and a narrower spatial distribution than locally produced seeds. Therefore, immigrant seeds showed higher diversity values than locally produced seeds.

Average seed size and the proportion of epigeous seedlings were similar in local and immigrant species. Under closed-canopied sites, factors affecting community organization seem to operate selectively, favoring the establishment of large-seeded, local abundant species in the advanced regeneration. However, the fact that some saplings of immigrant species were found in the plots suggest that a slow species infiltration may be occurring leading to a slow shift in the advanced regeneration species composition. We propose that the influence of seed dispersal on advanced regeneration structure depends on the disturbance history of the patches where seeds land.
\end{abstract}

Nomenclature: Scientific names and authorities follow Ibarra \& Sinaca (1987)

\section{Introduction}

During the last two decades, much attention has been paid to understand the role played by canopy gaps in the regeneration processes of tropical rain forest tree communities (Denslow 1987; Oldeman \& van Dijk 1991). These studies have indicated that seedling and sapling banks estab- lished before the opening of a gap are important to the gap-phase regeneration of the so-called non-pioneer or persistent species (Sarukhán et al. 1985; Brokaw 1985; Uhl et al. 1988; Raich \& Christiansen 1989). However, we are only beginning to understand how this advanced regeneration originates and becomes structured. Since the persistent trees constitute the principal compo- 
nent of diversity, structure and dynamics in these systems (Denslow 1987), this problem is an important ecological issue.

Seeds are a major source of propagules for rain forest regeneration. Seed rain falling beneath a mature tree is composed of seeds produced by the tree itself (local seeds) and by other trees (immigrant seeds). Locally produced seeds represent potential advanced self-regeneration whereas those seeds arriving via dispersal agents represent a potential advanced immigrant-regeneration. Although we can imagine that both types of regeneration take place, we don't know what proportion of the seedling and sapling banks found in closed-canopied sites originate from these two seed sources. In its final consequences, selfregeneration maintains a floristic forest mosaic whereas immigrant-regeneration may homogenize forest composition if seeds are widely dispersed or may create floristic heterogeneity if seed dispersal is patchy. Then, forest structure must be the result of the combination of these two regeneration alternatives and in order to better understand tropical forest structure, we must know the contribution of each alternative.

In tropical rain forests the main seed vectors are vertebrate frugivores (Terborgh 1990). Therefore, frugivory is expected to be an important factor in the organization of advanced regeneration. Under closed-canopies sites, low light availability (Pearcy 1990; Chazdon 1988), physical damage (Clark \& Clark 1989) and natural enemies (Augspurger 1984; Dirzo 1984; Clark \& Clark 1984; Schupp 1988a, b) are important mortality factors operating on seed and seedling populations. The probability of any species becoming established in advanced regeneration depends on how well its members can withstand mortality risks imposed by an environment that changes as plants develop from seed to later life-cycle stages. A complex of traits, including the initial amount of maternal resources (Foster, 1986; Howe 1990; Hladik \& Miquel 1990), antiherbivore defenses (Dirzo 1987), carbon balance (Pearcy 1990; Chazdon 1988) and seedling size ( $\mathrm{Ng} \mathrm{1978;} \mathrm{Sarukhán} \mathrm{et} \mathrm{al.}$ 1984), determines this probability (Primack 1990).
The action of mortality factors as part of controlling or regulating population mechanisms, may have very different consequences to the organization of advanced regeneration and to the structure of the whole forest community (Connell et al. 1984; Hubbell \& Foster 1986, 1990a). If populations are regulated by density or frequencydependent mechanisms, many species can persist in equilibrium. In contrast, if populations are controlled by density-independent mechanisms, diversity will be the result of a balance between local species extinction and colonization rates, ruled, to a great extent, by random events (Hubbell \& Foster 1986). Under these non-equilibrium circumstances, we can expect an unpredictable advanced regeneration structure and composition. In any community, however, these two sets of forces are present and their relative importance may change through space and time (Hubbell \& Foster 1990a; Hubbell \& Foster 1990b).

In 1988 we began a long-term study whose aims were to identify patterns, processes and mechanisms involved in the organization of advanced regeneration in the Los Tuxtlas rain forest. This paper presents data obtained during the first year. By comparison of the coexisting seed rain, seedling and sapling community structures we explore: i) the contribution of immigrant seeds to the seed rain falling in closed canopy sites, ii) the contribution of immigrant seeds to the seedling and sapling communities in those sites and iii) the existence of community organization mechanisms during advanced regeneration. Particularly, we take up the following questions: To what degree do dispersed seeds contribute to the species richness of the seed rain? Have seeds of trees maturing at different canopy heights the same chance to be dispersed? What is the contribution of these tree groups to the diversity of the seed rain and advanced regeneration communities? How does the initial community structure, represented by the seed rain, change as individuals develop to further life-cycle stages (i.e. seedlings and saplings)? What factors affect such transitions and what is their possible role in the organization of the advanced regeneration community? Although our main concern is centered on the tree commu- 
nity because ecological knowledge available for lianas is very limited (Putz 1983), we decided to include this life form in this study. In concluding, we discuss the possible roles played by the relationship between seed dispersal and forest dynamics in forest community organization.

\section{Material and methods}

This study was carried out at the Los Tuxtlas tropical field station in south-eastern Mexico (longitude $95^{\circ} 04^{\prime}$ latitude $18^{\circ} 34^{\prime} \mathrm{N}$ ). This locality represents the northernmost neotropical rain forest (Dirzo \& Miranda 1991). Average canopy height is about $25 \mathrm{~m}$, and tree community diversity is relatively low compared with other tropical rain forests (Bongers et al. 1988). However, more than 250 tree species, and nearly 900 vascular plants, have been found in the 700 ha preserve (Ibarra \& Sinaca 1987). Information on the climate, geology and general ecology of the locality can be found elsewhere (Gómez-Pompa \& Del Amo 1985).

We established five $25 \times 25 \mathrm{~m}$ permanent study plots in relatively flat, closed canopy forest sites in May 1988. Plot size represented forest areas similar to those affected by the largest treefall gaps at Los Tuxtlas (Popma et al. 1988). In each plot, all tree and liana species greater than $1 \mathrm{~cm}$ in diameter at breast height ( $\mathrm{dbh}$ ) were recorded and mapped. We define saplings as trees with a dbh $1-2 \mathrm{~cm}$. Sixty four uniformly spaced points were located at each site. We identified and recorded the species of all tree and liana crowns found over each point.

To measure seed rain, we placed twelve $1 \mathrm{~m}^{2}$ seed traps randomly on each plot. The trap material was collected monthly, from June 1988 to May 1989, and all apparently healthy seeds larger than $1 \mathrm{~mm}$ in length were identified and counted. We considered the seed rain community to be those species recorded in the traps during the year period. Average seed dry weight per species was also determined (G. Ibarra \& M. Martínez-Ramos unpubl.).

Seedling community structure was studied at sixteen $1 \mathrm{~m}^{2}$ permanent quadrats, randomly established within each study plot. In June 1988, all seedlings and saplings $\leq 1 \mathrm{~m}$ tall were identified, counted and mapped in each quadrat. Hereafter, these plants will be referred to as oldseedlings. Every three months, from June 1988 to May 1989, all new seedlings were recorded and marked in the quadrats. Hereafter, these seedlings will be referred as recruited-seedlings.

\section{Data analyses}

Although we recorded species whose seeds come from fleshy and dry fruits, in the present paper we limited the data analyses to those species whose fleshy fruits or arilate seeds suggest seed dispersal by animals. This was done in order to assess the role that frugivory has as an factor influencing advanced regeneration. Furthermore, wind dispersed species represented a minor fraction $(<15 \%)$ of the total number of species recorded in the seed rain and its omission did not change the results obtained in the present study (Martínez-Ramos \& A. Soto, unpubl.). Seed, seedling and sapling species were classified as belonging to i) trees or lianas, and coming from ii) a local or immigrant origin. Local species were those produced by mature plants whose crowns were found within the plot or touching the plot borders, while immigrant species were those for which crowns of parent plants were completely outside the plots. Therefore, we assumed that immigrant species were brought in by animal dispersers.

Seed, seedlings and sapling species were assigned to the following tree groups: Low-Canopy ( $\mathrm{LC}=$ tree species maturing at heights lower than $10 \mathrm{~m}$ ), Mid-Canopy ( $\mathrm{MC}=$ tree species maturing at heights lower than $20 \mathrm{~m}$ ) or Upper-Canopy (UC $=$ species maturing at height taller than $20 \mathrm{~m}$ ). The $\mathrm{L}$ group included liana species.

To determine whether rates of seed dispersal differ among species found at different canopy heights, we constructed the following hypothesis: The probability of detecting at least one seed at a given point in the forest produced by species found at different canopy height positions de- 
pends only on the proportion in which these species are represented in the entire tree community. To evaluate the null hypothesis we used i) the community structure data (woody plants $\geq 1 \mathrm{~cm}$ dbh) available for a 1 ha plot at Los Tuxtlas forest (Bongers et al. 1988) and ii) an intensive check-list of seeds and fruits produced by trees and liana species at the same forest (G. Ibarra \& M. Martínez-Ramos unpubl.). From these two sources, only species that produce fleshy fruits or arillate seeds were considered. Tree and liana species recorded in the 1-ha plot on the one hand, and in the check-list on the other hand, were placed into the LC, MC, UC and L groups. The resulting proportions from the two sources were averaged to yield the expected random proportions for each plant group. The null hypothesis was tested using Chi-square tests, comparing the local and immigrant seed, seedling and sapling communities. Because of the small sample sizes available in the majority of the study plots, the five plots were pooled for the statistical analyses. We considered local species as those having either seeds, seedlings or saplings and mature individuals in at least one of the five study plots.

We calculated species richness $(\mathrm{S}=$ number of species in the sample), diversity (H'ShannonWiener Index) and equitability $\left(\mathbf{J}=\mathrm{H}^{\prime} / \mathrm{Ln}(\mathrm{S})\right)$, by combining all plots. The calculations were made for: i) each plant group, ii) the entire tree community, and iii) the tree plus liana community. An index of species similarity was computed in order to estimate the probability that species recorded at a given life-cycle stage (seed, recruited-seedling, old-seedling or sapling) were also present in the next stage. This index measures the proportion of species shared by two samples (Greig-Smith 1983). We calculated species similarity for all tree species and for local and immigrant species separately.

An indicator of the seedling shade-tolerance was obtained by using i) the mean dry seed weight per species (Foster 1986), and ii) the initial morphology of seedlings. Initial morphology was classified into two categories: seedlings with photosynthetic cotyledons (PC-seedlings) and seed- lings with cotyledons, hypocotyl and/or endosperm functioning as reserve organs (RCseedlings). The first category corresponds to the epigeal germination type and the second one to the hypogeal, semi-hypogeal and durian germination types proposed by $\mathrm{Ng}$ (1978) and Hladik \& Miquel (1990). Elsewhere, it has been shown that RC-seedlings, mostly emerging from large seeds, have a significantly higher survivorship than PCseedlings under closed canopy conditions (Martínez-Ramos 1991).

\section{Results}

Forest community structure in the study plots

Two of the five study plots were located in successional forest patches ('building' sensu Whitmore 1989), and were dominated by the pioneer tree Cecropia obtusifolia (Moraceae). These patches were disturbed by the opening of tree-fall gaps eight and twenty years ago, respectively. The younger patch showed the highest frequency of small trees $(\leq 5 \mathrm{~cm} \mathrm{dbh})$ of the five study plots. The twenty year-old patch showed highest frequencies of medium-sized trees $(10-20 \mathrm{~cm} \mathrm{dbh})$. The other three plots were localized in forest patches in mature phase (sensu Whitmore 1989). Two of these patches were dominated by Nectandra ambigens (Lauraceae), the most abundant upper-canopy tree at Los Tuxtlas. The third represented a diverse patch with trees of Ficus yoponensis (Moraceae), Pseudolmedia oxyphyllaria (Moraceae) and Cordia megalantha (Boraginaceae) as the species with highest total community basal area and crown cover (Martínez-Ramos 1991). The frequency of seedlings and small saplings ( $\leq 1 \mathrm{~m}$ in height) in the mature patches was significantly higher than in the two building forest patches $\left(\chi^{2}=17.2, \mathrm{DF}=4, \mathrm{P}<0.01\right.$; Table 1$)$.

Notwithstanding the above differences among plots, community diversity was quite similar and high in all of the plots (S range: 26-34, H'range: $2.73-2.89 ; \mathrm{J}$ range $=0.84-0.87)$ (Table 1$)$. 
Table 1. Tree community structure in the five study plots at Los Tuxtlas tropical rain forest. Patch age indicates the time elapsed since the last treefall detected in the plot (accordingly to Martínez-Ramos et al. 1988a). Seedling and sapling density refers to plants $\leq 1 \mathrm{~m}$ in height. Tree density, $\mathrm{S}, \mathrm{H}^{\prime}$ and $\mathrm{J}$ refer to plants with $\mathrm{dbh} \geq 1 \mathrm{~cm}$. All values are given for $25 \times 25 \mathrm{~m}$ plots.

\begin{tabular}{|c|c|c|c|c|c|}
\hline & \multicolumn{5}{|l|}{ Plots } \\
\hline & 1 & 2 & 3 & 4 & 5 \\
\hline Patch age (yrs) & $>35$ & $>35$ & 20 & $>35$ & 8 \\
\hline Seedling \& sapling density & 7,092 & 13,767 & 3,963 & 11,458 & 2,593 \\
\hline Tree density & 69 & 60 & 62 & 51 & 81 \\
\hline Number of species (S) & 31 & 33 & 30 & 25 & 31 \\
\hline Shannon index $\left(\mathrm{H}^{\prime}\right)$ & 2.51 & 2.89 & 2.73 & 2.63 & 2.55 \\
\hline Equitability (J) & 0.84 & 0.86 & 0.84 & 0.87 & 0.85 \\
\hline
\end{tabular}

\section{Null hypothesis community}

One hundred and eleven tree and liana species, producing fleshy fruits or arillate seeds, occurred on the 1-ha plot, and 174 tree and liana species occurred in the check-list. There were no significant differences in species frequency between these two sources of data when species were classified in LC, MC, UP and L plant groups $\chi^{2}=2.76, \mathrm{DF}=3, P>0.50$ ). When both sources were averaged, percentages per plant group were: $\mathrm{LC}=40.6, \mathrm{MC}=15.7, \mathrm{UC}=27.3, \mathrm{~L}=16$.

Seed rain, advanced regeneration and the null dispersal hypothesis

Seeds

A total of 160 species in 59 families was recorded in the plots over the course of the study. Fifty two per cent ( 88 species) were tree and liana species that produce fleshy fruits or arillate seeds. The rest were species with dry fruits or that belong to other life forms (palms and herbs).

Of the fleshy-fruited tree and liana species, $54.6 \%$ of the species were classified as arriving from outside of the plots (Table 2). This value varied among height groups. Lianas and UC trees showed the highest percentages and LC trees the lowest, both at an individual plot level (Table 2) and when all plots were pooled (Fig. 1). Immigrant liana seeds, and to a lesser extend those produced by UC and MC trees, showed a signif- icantly higher species frequency than expected by chance (Fig. 1). When the liana group was omitted from the analysis, then LC species become under-represented whereas UC and MC species show even higher frequencies than expected by chance $\left(\chi^{2}=6.0, \mathrm{DF}=2, P<0.05\right)$. The species frequency per height group in local seeds did not differ from those expected by chance (Fig. 1).

\section{Recruited-seedlings}

A total of 56 species was recorded as recruitedseedlings in the five plots. Immigrant seedling species accounted for $48.2 \%$ of the total (Table 2). Immigrant liana seedlings tended to be over-represented and immigrant LC seedlings under-represented (Table 2). Pooling all plots, species frequency of immigrant liana and UC seedlings were significantly higher than that expected by chance (Fig. 1). Species frequency per plant group in locally recruited-seedlings reflected the community structure of the forest (Fig. 1).

\section{Old-seedlings}

In the old-seedling community, 60 tree and liana species were found in the five study plots. Immigrant species accounted for a significantly lower percentage $\left(\chi^{2}=3.29, P<0.10\right)$ than locally produced seedlings to the total number of species (Table 2) and, in contrast to the seed rain and recruited-seedling communities, species frequencies of local and immigrant height groups were quite similar within each plot and when all plots were combined (Table 2). Species frequency of 
Table 2. Seed rain, recruited-seedling and old-seedling community species richness under five closed sites in the Los Tuxtlas rain forest, Mexico. $\mathrm{LC}=$ low-canopy (mature trees $<10 \mathrm{~m}$ height), $\mathrm{MC}=$ mid-canopy $(10.1-20 \mathrm{~m}$ height), $\mathrm{UC}=$ upper-canopy $(>20 \mathrm{~m}$ height), $\mathrm{L}=$ lianas. $\mathrm{I}=$ immigrant species, $\mathrm{L}=$ local species. The $\mathrm{I} / \mathrm{T}$ ratio measures the percentage of immigrant species out of the total species richness.

Number of species by plot

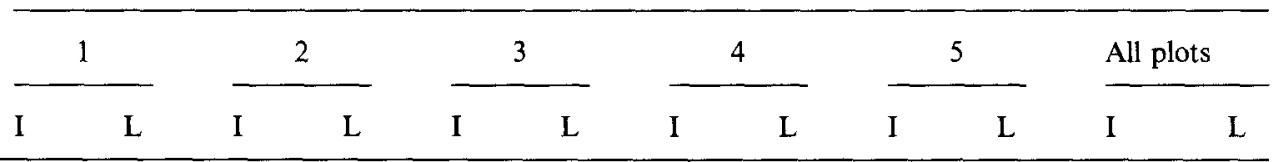

1) Seed rain

$\begin{array}{lrrrrrrrrrrrr}\text { LC } & 5 & 1 & 2 & 5 & 4 & 7 & 4 & 5 & 9 & 1 & 8 & 12 \\ \text { MC } & 9 & 2 & 4 & 4 & 3 & 2 & 2 & 3 & 5 & 3 & 9 & 6 \\ \text { UC } & 14 & 5 & 13 & 6 & 14 & 6 & 11 & 8 & 8 & 6 & 13 & 14 \\ \text { L } & 12 & 2 & 8 & 0 & 14 & 1 & 8 & 4 & 13 & 3 & 18 & 8 \\ \text { Total } & 40 & 10 & 27 & 15 & 35 & 16 & 25 & 20 & 35 & 13 & 48 & 40 \\ \text { I/T(\%) } & 80.0 & & 64.3 & & 68.6 & & 55.6 & & 72.9 & & 54.6 & \end{array}$

2) Recruited-seedling

$\begin{array}{lccccccccccrr}\text { LC } & 2 & 4 & 2 & 3 & 1 & 0 & 2 & 5 & 1 & 2 & 5 & 10 \\ \text { MC } & 3 & 1 & 2 & 2 & 2 & 2 & 2 & 1 & 1 & 0 & 4 & 4 \\ \text { UC } & 1 & 4 & 3 & 3 & 5 & 5 & 5 & 4 & 2 & 2 & 9 & 10 \\ \text { L } & 4 & 2 & 2 & 0 & 6 & 0 & 3 & 3 & 0 & 1 & 9 & 5 \\ \text { Total } & 10 & 11 & 9 & 8 & 14 & 7 & 12 & 13 & 4 & 5 & 27 & 29 \\ \text { I/T(\%) } & 47.6 & & 52.9 & & 66.7 & & 48.0 & & 44.4 & & 48.2 & \end{array}$

3) Old-seedling

$\begin{array}{lcccccccccccr}\text { LC } & 9 & 8 & 6 & 9 & 5 & 6 & 6 & 5 & 6 & 5 & 9 & 13 \\ \text { MC } & 5 & 2 & 4 & 1 & 5 & 2 & 3 & 3 & 3 & 2 & 6 & 5 \\ \text { UC } & 4 & 5 & 4 & 4 & 3 & 4 & 6 & 4 & 3 & 6 & 4 & 10 \\ \text { L } & 4 & 5 & 5 & 3 & 5 & 2 & 8 & 3 & 7 & 2 & 4 & 9 \\ \text { Total } & 22 & 20 & 19 & 17 & 18 & 14 & 23 & 15 & 19 & 15 & 23 & 37 \\ \text { I/T }(\%) & 52.4 & & 52.8 & & 56.3 & & 60.5 & & 55.9 & & 38.3\end{array}$

immigrant and local old-seedlings reflected the community structure of the forest (Fig. 1).

\section{Saplings}

We pooled our data on tree saplings for statistical analysis. For the liana group we did not take any sapling data. A total of 21 tree species was recorded in the five study plots. Immigrant species were the minor component of species richness in the community $(28.6 \%$ of the total; $\chi^{2}=3.86, \mathrm{DF}=1, \mathrm{P}=0.05$ ). In the UC tree group no immigrant species were found. Combining immigrant and local species, LC saplings showed the highest species frequency $(42.9 \%$ of the total) whereas UC saplings showed the lowest (Fig. 1). These frequencies were not statistically different from those expected under a random distribution (Fig. 1).

Changes in community structure among life-cycle stages

\section{Species richness}

A reduction in the number of species occurred from the seed stage to later stages (see Fig. 3). As 

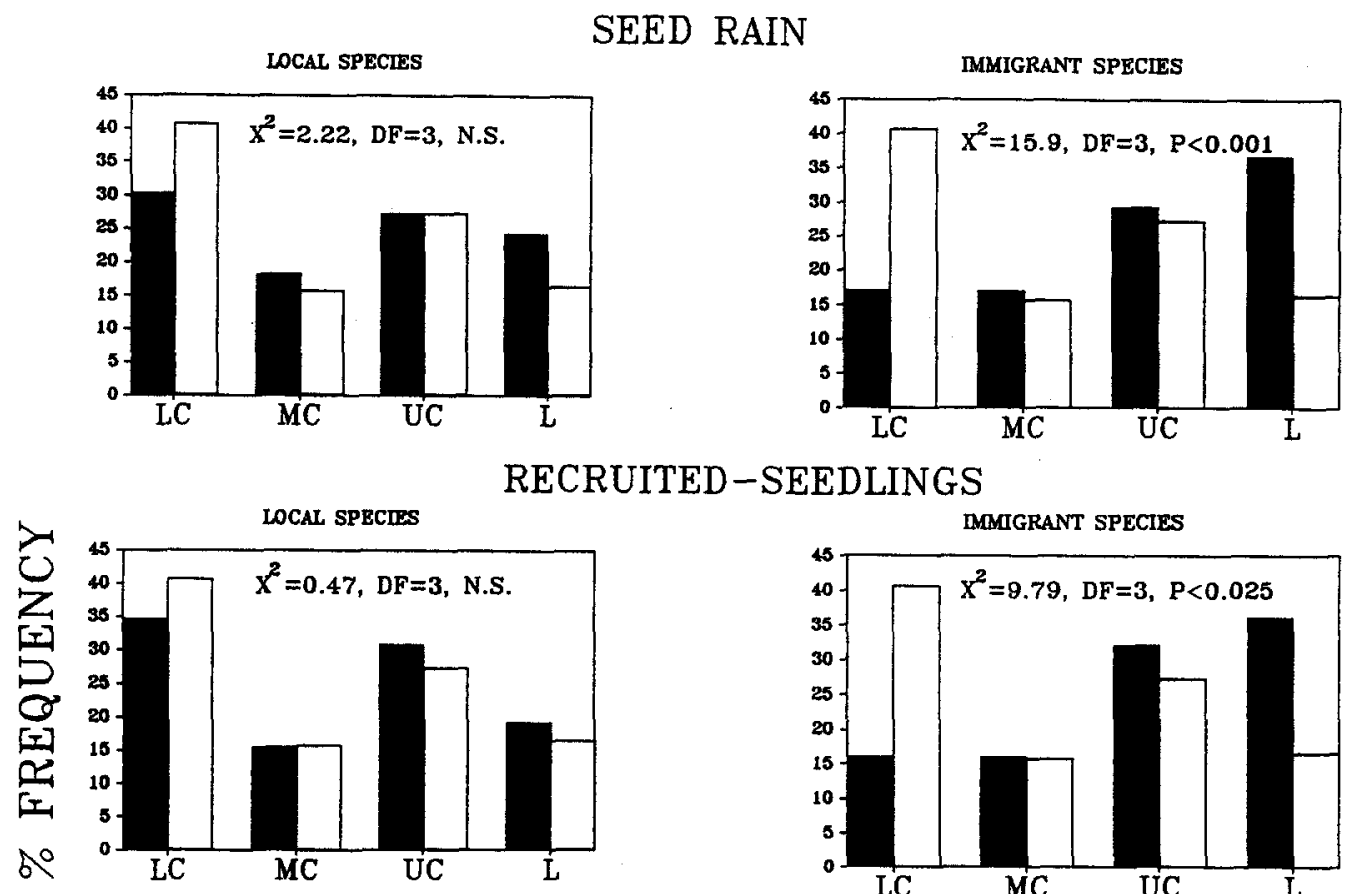

MMIGRANT SPECTES
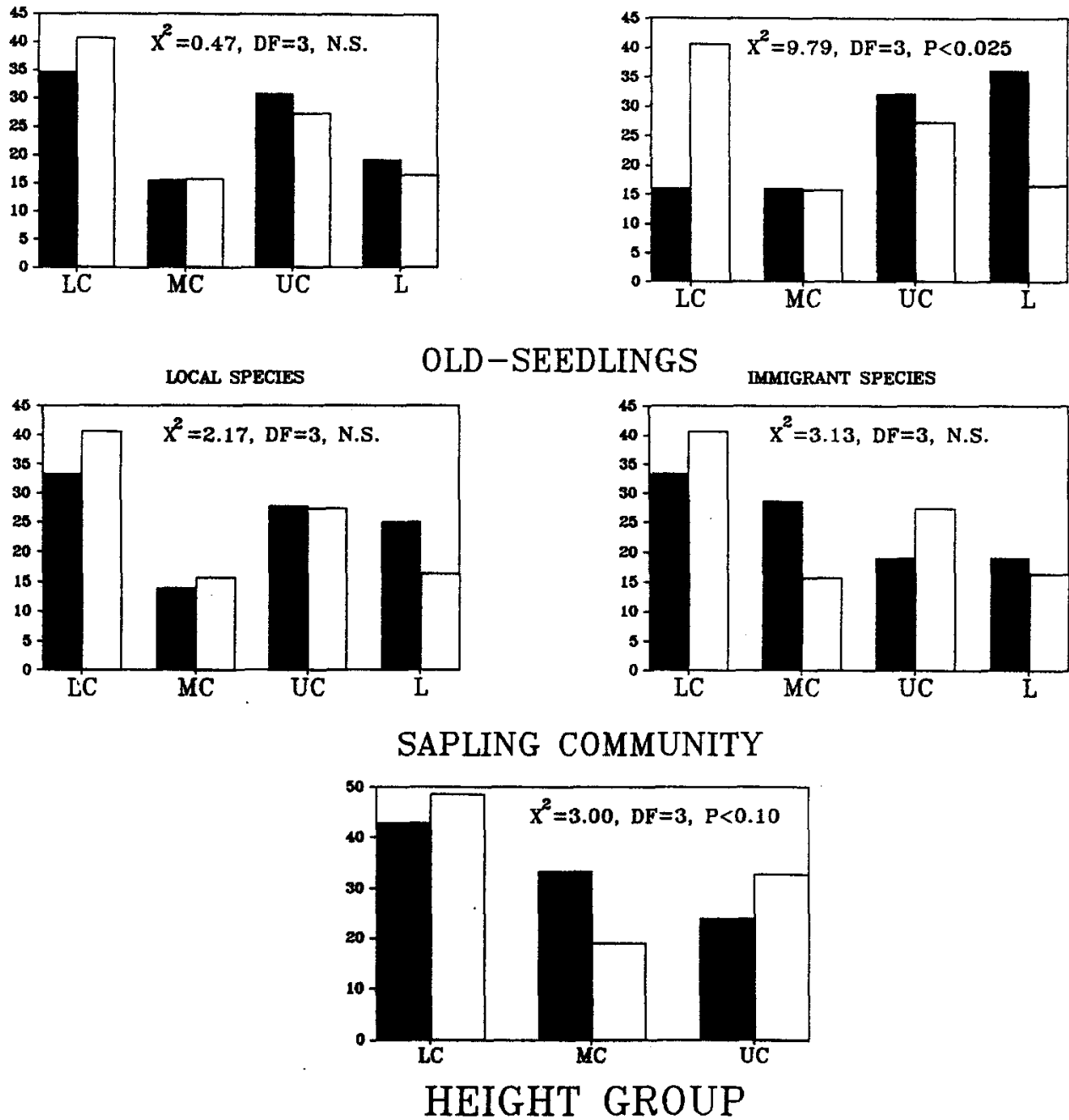

Fig. 1. Observed (filled bars) and expected (open bars) (under a dispersal null hypothesis) species frequencies per height group in local and immigrant species for: Seed rain, recruited-seedling, old-seedling and sapling communities in closed sites of Los Tuxtlas forest. Results of $\chi^{2}$ analysis are indicated inside each graph. See text for further details. 
a result, only $30 \%$ of the total number of tree species recorded in the seed rain were also found in the sapling community (Fig. 2).

Species similarity between communities representing different life-cycle stages clearly showed lower values for immigrant species than for local ones (Fig. 2). This result suggests that transition probabilities among life-cycle stages are higher for locally produced seeds than for immigrant seeds.

Diversity: relative abundance among species

Associated with the decreasing species richness recorded from the seed rain to sapling communities, more abundant species suffered a strong thinning effect. Consequently community diversity and equitability increased along this sequence (Fig. 3). Immigrant species were less abundant compared to local species in all the life-cycle stages. A Chi-square analysis showed that local height groups in all life-cycle stages had a significantly higher frequency of common species ( $>4$ individuals per species in the five plots) than did the immigrant groups $(P<0.01)$. In terms of interplot frequency, immigrant species were also rare. Most immigrant species were found in only one of the five study plots. In contrast, most local species were widely distributed through the plots (Fig. 4).

The most abundant species had different community abundance positions in different life-cycle stages (Fig. 3). Small-seeded and light-demanding trees Cecropia obtusifolia (Moraceae), Lunania mexicana (Flacourtiaceae), Ficus yoponensis (Moraceae), and Dendropanax arboreous (Araliaceae), which were the most common species in the seed rain community, were rarely (C. obtusifolia, D. arboreous) or never recorded (L. mexicana, $F$. yoponensis) in later stages. This presumably reflects the inability of these species to establish in the shade. The reduction in abundance of these species increased diversity in the recruitedseedling community (Fig. 3). Other reasons appear to explain the changes in abundance that occurred in some persistent species. For example, the decrease in abundance of Pseudolmedia oxyphyllaria (Moraceae), a large seeded (average dry weight: $500 \mathrm{mg} \mathrm{seed}^{-1}$ ) shade-tolerant tree and sixth in abundance in the seed rain community

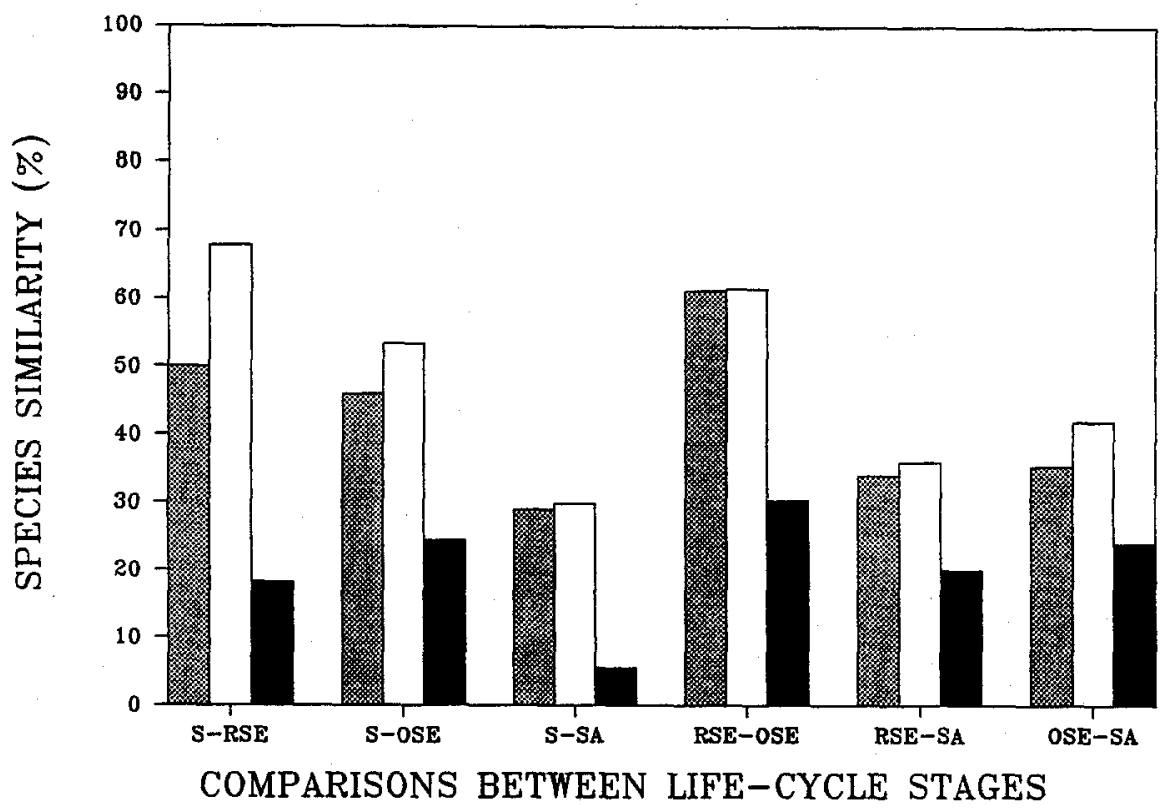

Fig. 2. Index of species similarity values obtained for pair-wise comparisons between seed rain (S), recruited-seedling (RSE), old-seedling (OSE) and sapling (SA) communities. Values for all species are gray bars, values for local species are white bars and values for immigrant species are black bars. 


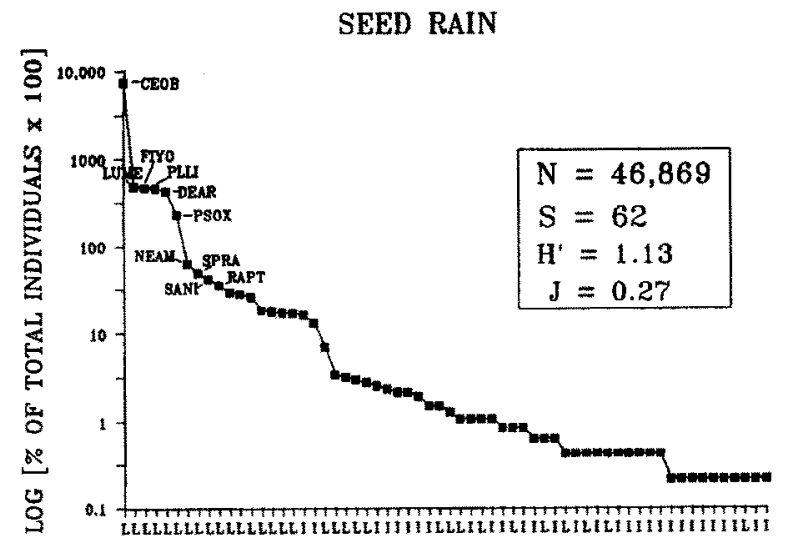

OLD-SEEDLINGS

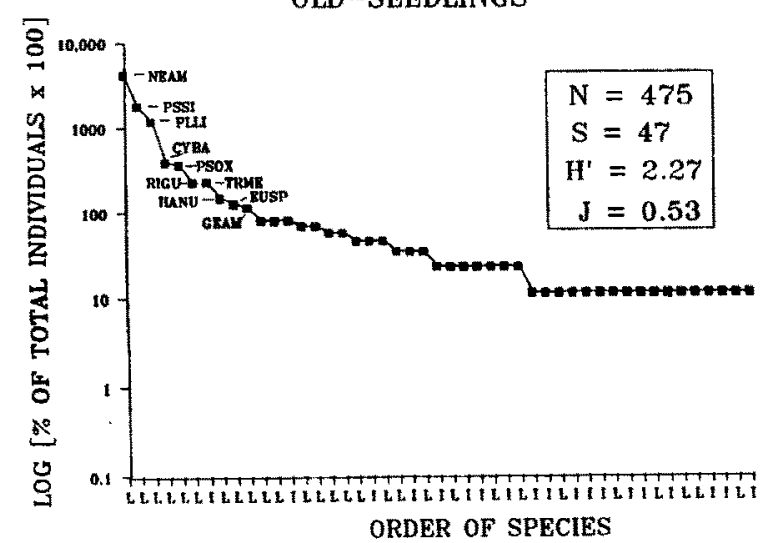

RECRIUTED-SEEDLINGS

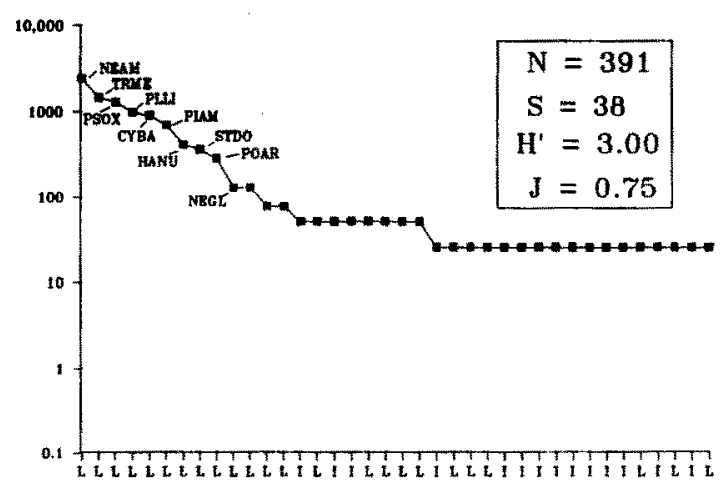

SAPLINGS

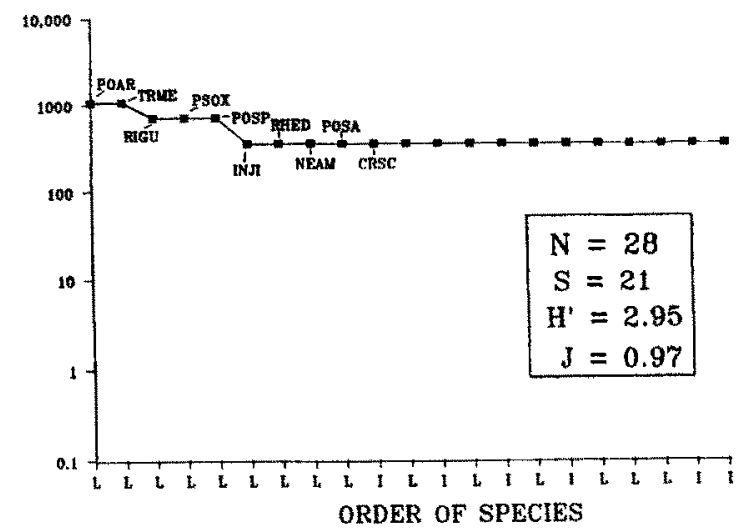

Fig. 3. Dominance-diversity curves for seed rain, recruited-seedling, old-seedling and sapling communities in closed forest sites at Los Tuxtlas. The number of individuals $(\mathrm{N})$, species richness $(\mathrm{S})$, diversity $\left(\mathrm{H}^{\prime}\right)$ and equitability $(\mathrm{J})$ are given in each case. The ten most abundant species are indicated in each community. In the $\mathrm{X}$-axes, $\mathrm{L}$ indicates local species and $\mathrm{I}$ the immigrant ones. Species codes correspond to the following tree species: CEOB (Cecropia obtusifolia), CRSC (Croton schedianus), CYBA (Cymbopetalum baillonii), DEAR (Dendropanax arboreous), EUSP (Eugenia sp), FIYO (Ficus yoponensis), HANU (Hampea nutricea), GEAM (Genipa americana), INJI (Inga jinicuil), LUME (Lunannia mexicana), NEAM (Nectandra ambigens), NEGL (Nectandra globosa), PIAM (Piper amalago), PLLI (Pleuranthodendron lindenii), POAR (Poulsenia armata), PSOX (Pseudolmedia oxyphyllaria), RAPT (Randia pterocarpa), RIGU (Rinora guatemalensis), RHED (Rheedia edulis), SANI (Sapium nitidum), SPRA (Spondias radlkoferi), STDO (Stemadenia donnell-smithii), TRME (Trophis mexicana), POSA (Pouteria sapota), POSP (Pouteria sp).

(Fig. 3), from the seed to seedling stages was mainly due to seed predation by rodents (Martínez-Ramos 1991). In comparison, Nectandra ambigens (Lauraceae), an upper-canopy tree which produces large crops of big seeds (average dry weight: $1800 \mathrm{mg} \mathrm{seed-}^{-1}$ ) and seventh in abundance in the seed rain community (Fig. 3), suffered lower seed predation rates than $P$. oxyphyllaria (Martínez-Ramos 1991). Thus, differences in the rates of seed predation between these spe- cies may explain why in the seedling community the abundance position of $N$. ambigens was one order of magnitude higher than $P$. oxyphyllaria (Fig. 3). Supra-annual variability in fruiting behavior and high seedling survivorship of Trophis mexicana (Moraceae) (Martínez-Ramos 1991) may explain why this species was not found in the seed rain in the year studied, whereas it was one of the ten most abundant species in the seedling and sapling communities (Fig. 3). 

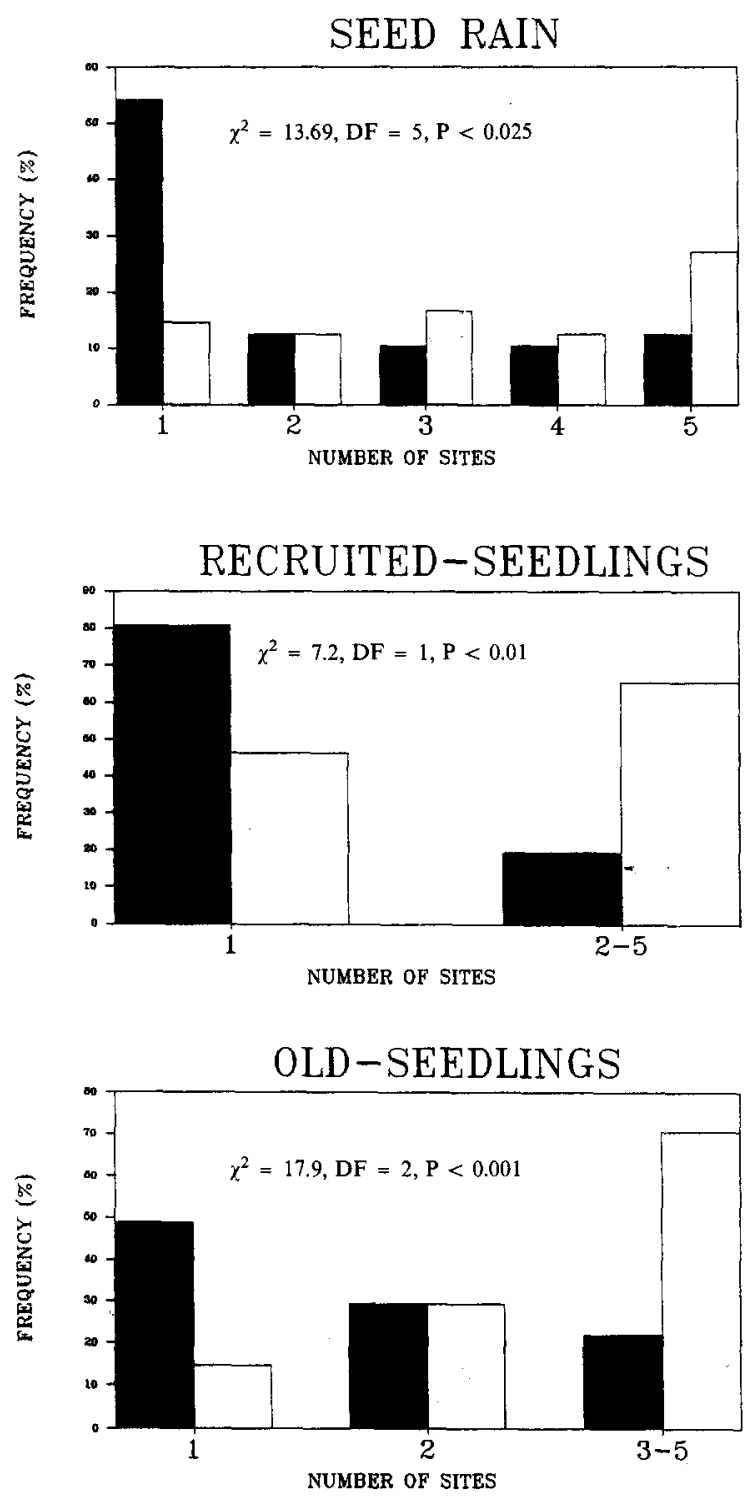

Fig. 4. Spatial frequencies of immigrant (filled bars) and local (open bars) species in the seed rain, recruited-seedling and old-seedling communities.

Pooling all height groups (including the lianas), immigrant seeds showed higher levels of diversity than locally produced seeds, and they were important components of the diversity observed in the seed rain community (Fig. 5a). However, in later life-cycle stages, the relative contribution of immigrant seed species to overall community diversity decreased (Fig. 5a). Diversity and equitability in the immigrant plants remained relatively constant among the different life-cycle stages but increased in the local plants (Fig. 5a, b). The small difference in diversity between local and immigrant tree species observed in the seedling and sapling communities (Fig. 5a) was due to an increase in equitability in the local species (Fig. 5b). Because most species in the sapling community were local species (Fig. 3), local saplings were more diverse than immigrant saplings (Fig. 5a).

When height groups were analyzed separately, few differences with respect to the above trends were observed. Lianas showed the highest diversity among all height groups (Fig. 5a). Among tree groups, UC seeds, seedlings and saplings showed the lowest diversity values while the highest ones were found in the LC groups (Fig. 5a). Within the MC group, immigrant communities had consistently higher diversity values than local ones (Fig. 5a).

Species transition between life-cycle stages and some of its possible determinants

From the above results it is apparent that immigrant propagules make an important contribution to the community structure observed in the seed rain and, to a lesser degree, to that of seedlings and saplings. Which seed species arriving at the forest soil eventually establish as seedlings and saplings? Here, we explore three life-history traits that can influence establishment under the shade conditions of the forest. Because of insufficient data for statistical analysis in the liana group, the following results include only tree species.

\section{Seed size}

It can be assumed that seed size is positively related to the amount of maternal investment per seed (Fenner 1985; Foster 1986). If larger maternal investments confer higher probabilities of seedling survival, we would expect that tree species producing large seeds have a higher chance of being represented in the seedling and later lifecycle stages. In fact, there was an increase in the average seed size per species from the seed to sapling communities $\left(\mathrm{F}_{3,158}=3.57, \quad P<0.01\right)$; 
however, the only significant difference detected was between the average seed size of species found in the seed rain and that of species found in the old-seedlings and saplings communities (Fig. 6a). A two-way analysis of variance did not detect a significant interaction effect on the average seed size either between life-cycle stages and the origin of propagules (i.e. immigrant vs local; $F_{3,154}=0.72, \quad P=0.52$ ) nor between life-cycle stages and tree groups $\left(F_{6,150}=0.70, P=0.56\right)$. Finally, there was no significant difference in mean seed size among either LC, MC and UC groups $\left(F_{2,156}=0.44, P=0.65\right)$ nor between local and immigrant species $\left(F_{1,160}=2.63, P=0.11\right)$.

\section{Seedling morphology}

Initial morphology of tree seedlings was the second attribute that we analyzed. We investigated the idea that, under shade conditions, seedlings having large maternal reserves (which we termed RC-species) would have higher survivorship probabilities than seedlings with epigeous, photosynthetic, cotyledons (PC-species). In our seed rain sample, species that procedure RC-seedlings had significantly larger seeds $(\bar{X} \pm S E=$ $2.81 \pm 0.11 \mathrm{mg}$ [log scale]) than those producing PC-seedlings $\left(\bar{X}_{ \pm} S E=1.44+0.13 \mathrm{mg}\right)$ $(t=7.33, D F=60, P<0.001)$. Photosynthetic cotyledons should play an important role in seedling establishment in sunny conditions but not in shade conditions (Ng 1978; Hladik \& Miquel 1990; Martínez-Ramos 1991). If so then we would expect the ratio $\mathrm{RC}$-species/ $\mathrm{PC}$-species to increase from the seed to sapling communities. A contingence table analysis made with a log-linear model (MacCullagh \& Nelder 1983) showed that the ratio $\mathrm{RC}$-species/PC-species differs significantly among life-cycle stages $\left(\chi^{2}=13.36, D F=3\right.$, $P<0.001)$. The proportion of CR-species was not significantly different between the seed rain and recruited-seedling communities, but this proportion was significantly higher in the old-seedlings and sapling communities (Fig. 6b). The higher number of epigeous species in the seed rain $(63 \%$ of the total number of species) indicates that this type of seedling morphology predominates in the entire tree community at Los Tuxtlas. The fact that a very similar $\mathrm{RC} / \mathrm{PC}$ ratio was detected in the seed rain and recruited seedling communities indicates that species producing one or the other type of seedling have similar probabilities of germination and recruitment as new seedlings. A contingency table analysis made with a log-linear model showed that the frequency of species producing RC- or PC-seedlings was not significantly different either with respect to tree canopy positions (LC, MC and UC groups; $\chi^{2}=2.13, D F=2$, $P>0.10$ ) or to origin of seeds (local or immigrant; $\chi^{2}=0.84, D F=1, P>0.10$ ).

\section{Species abundance}

Abundance may determine the probability that a given species reaches later life-cycle stages. If mortality probabilities are the same for all species, we can expect that rare (low abundance) species have a higher risk of extinction than abundant species. To explore this idea, seed rain, recruited-seedling and old-seedling communities were divided in four categories: 1) local species recorded in the life-cycle stage $i$ and in the next $i$ stage (i.e. remaining local species -RLS-), 2) local species whose individuals presumably died in stage $i$ and therefore are not recorded in the stage $i$ (i.e. extinct local species -ELS-), 3 ) immigrant species present in the $i$ and $i$ stages (i.e. remaining immigrant species -RIS-), and 4) immigrant species present only in the $i$ stage (i.e. extinct immigrant species -EIS-). Next, each of these species groups were arbitrarily divided into two abundance categories: 1) 'rare' species, with $\leq 4$ individuals and 2) 'abundant' species, with $>4$ individuals, considering population sizes recorded in the five study plots. With the data available, only these two categories were amenable to statistical analysis. To determine whether species frequency in each of the above four groups was independent of species abundance, we constructed a null hypothesis by obtaining the proportion of rare and abundant species in the entire community for each of the life-cycle stages. These proportions were then multiplied by the species number recorded for RLS, ELS, Ris, and EIS groups to obtain the expected random frequencies of rare and abundant species within each 
(A)

WHOLE COMMUNITY
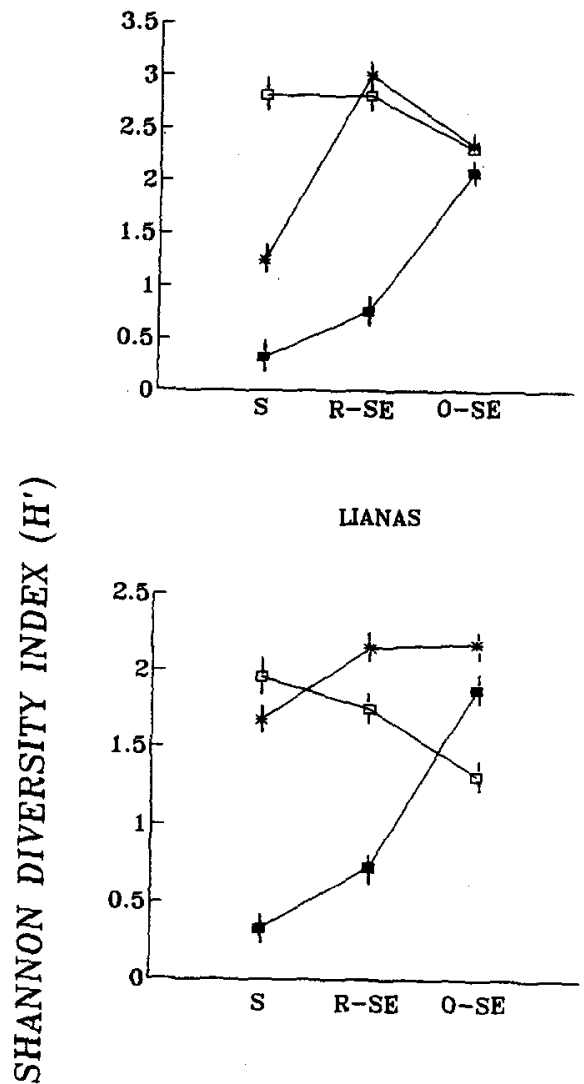

MID-CANOPY TREES

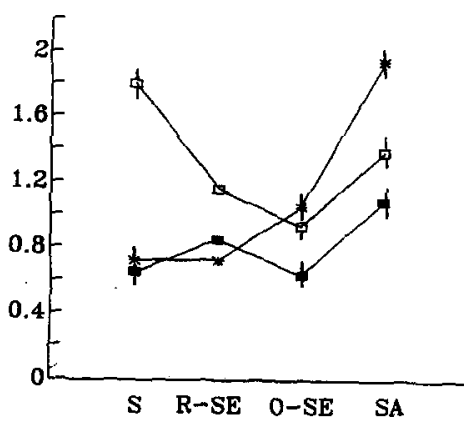

ALL TREES

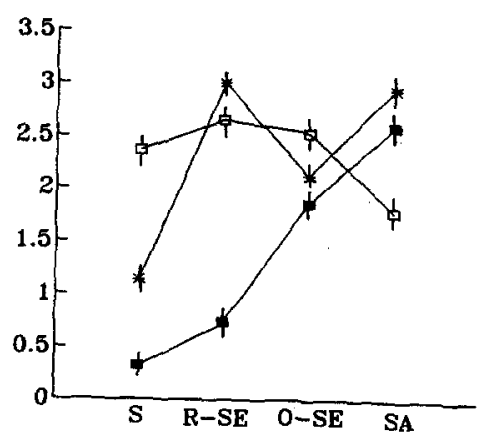

LOW-CANOPY TREES

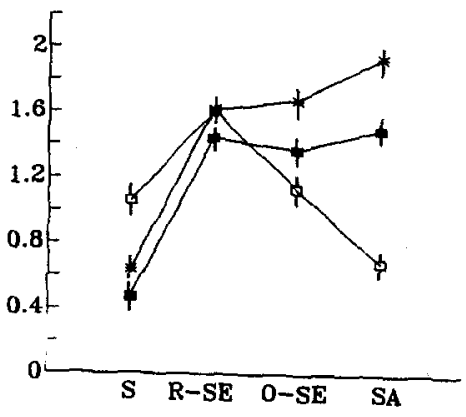

UPPER-CANOPY TREES

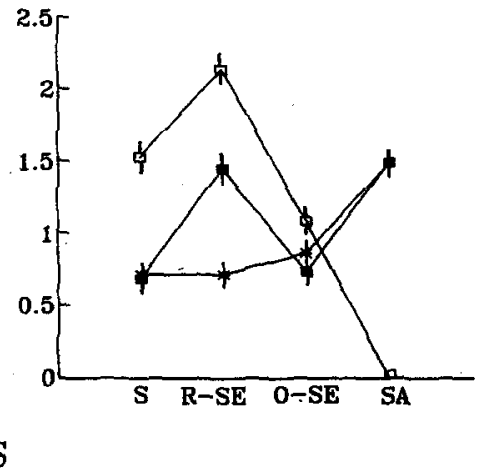

group. The observed and expected values were compared using Chi-square tests.

In the seed rain community (immigrant plus local species), remaining species were predomi- nantly abundant; rare species were more likely to go extinct (Fig. 7). In the recruited-seedling community, extinct species were also predominantly rare. In the old-seedling community remaining 
(B)

WHOLE COMMUNITY
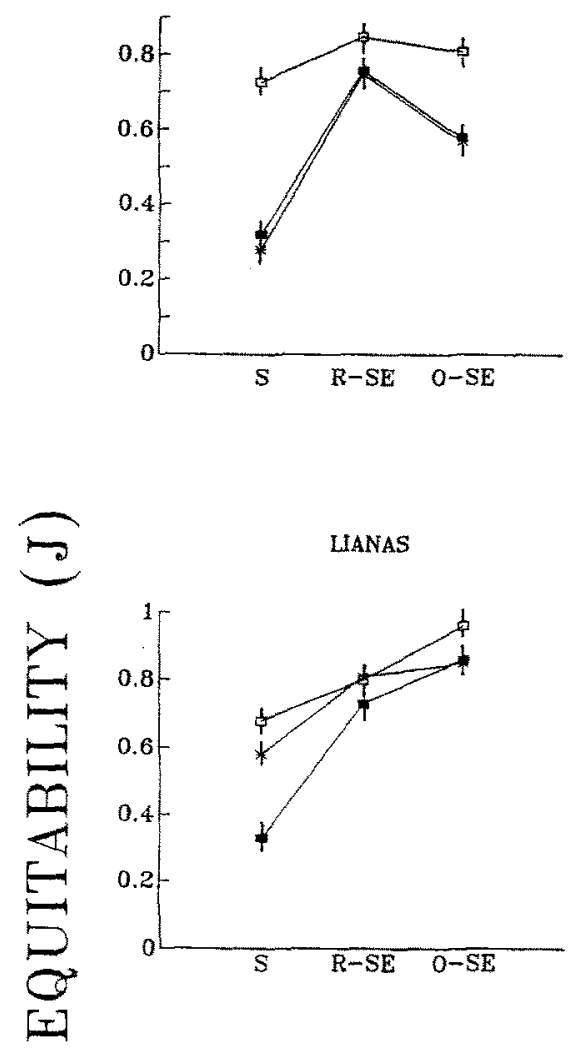

MID-CANOPY TREES

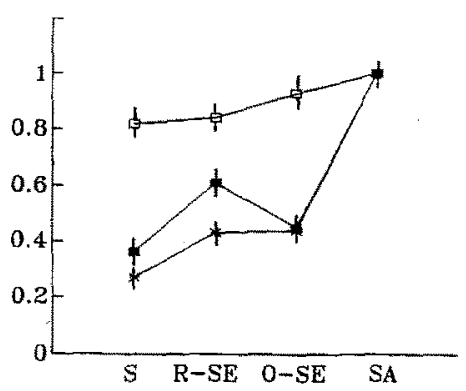

ALL TREES

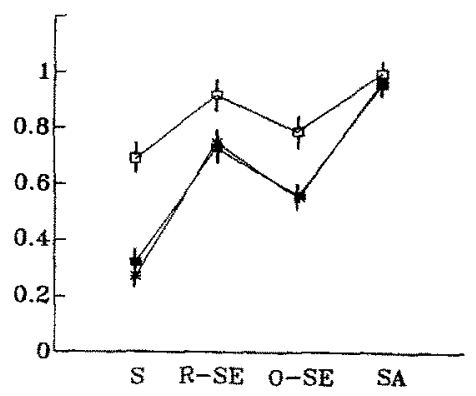

LOW-CANOPY TREES

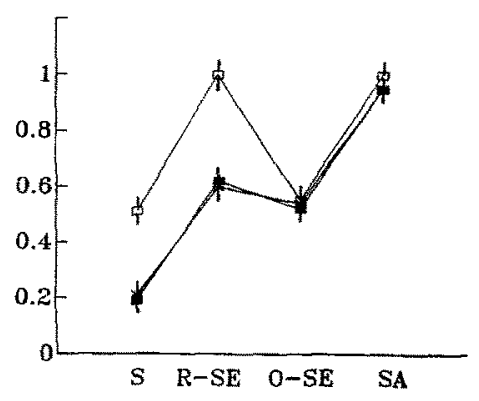

UPPER-CANOPY TREES

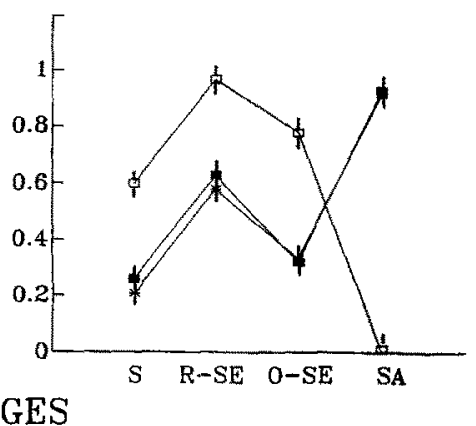

Fig. 5. Diversity (A) and equitability (B) changes among life-cycle stages in the entire community (lianas plus trees), in the tree and liana communities, and in different canopy positions of trees. In each case the values for local, immigrant and all species are shown. $\mathrm{S}=$ seeds, $\mathrm{R}-\mathrm{SE}=$ recruited seedlings, $\mathrm{O}-\mathrm{SE}=$ old seedlings, $\mathrm{SA}=$ saplings. Vertical lines represent two standard errors. $\square=$ immigrant species, $\square=$ local species, $\star$ = all species. 


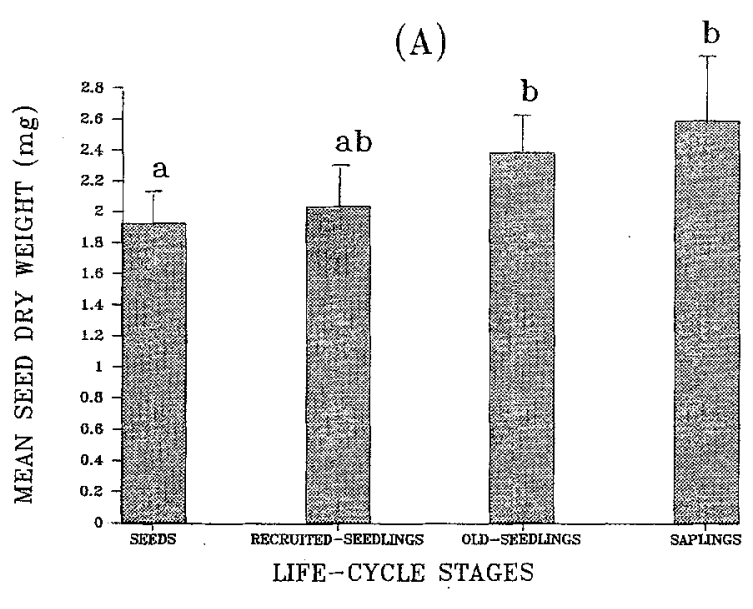

$\mathrm{b}$

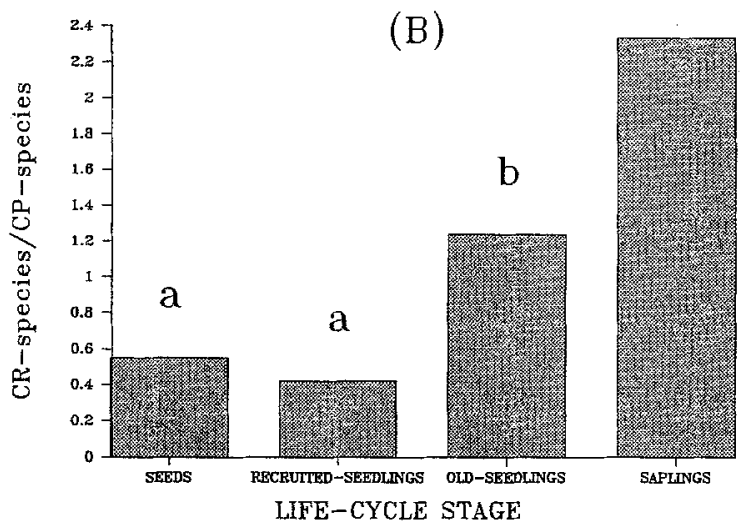

Fig. 6. Changes in (A) average seed weight (on a log-scale) and (B) the ratio of RC-species/PC-species among early lifecycle stages of the tree community found in closed forest sites at Los Tuxtlas; $\mathrm{PC}$-species $=$ species producing seedlings with photosynthetic cotelydons, $\mathrm{RC}$-species = species producing seedlings with cotelydons, endosperm or hypocotyl functioning as reserve organs. Vertical lines indicates two standard errors. Bars that share the same letters are not statistically different $(P<0.05)$.

species were predominantly abundant. When local and immigrant species were analyzed separately, it was clear that the RLS group was significantly over-represented by abundant species in all life-cycle stages. In contrast, the EIS group included a significantly higher frequency of low abundance species in most life-cycle stages (Fig. 7).

Overall, the above results suggest that abundant species have higher probabilities of being represented in the next stage, and that probability was higher for local than for immigrant species. However, several rare species of immigrant origin were also recorded in the sapling community (Fig. 3). Therefore, other factors besides species abundance alone, seem to influence the species persistence over time.

\section{Discussion}

Three major points emerged from this study: i) Immigrant species are a significant component of diversity for both the seed rain and seedling communities in closed canopy sites, ii) contribution to the seed rain depends on position in the canopy; seeds of upper-canopy trees and liana species were the major components of the immigrant seed community, and iii) under closed-canopied sites, factors affecting community organization seem to operate selectively, favoring the establishment of large-seeded, local abundant species in the advanced regeneration.

\section{Seed dispersal, forest community structure and seed rain}

The estimated contribution of immigrant species to the seed rain based on only one year can be only a rough estimate, since this is an extremely variable phenomenon. Spatial and temporal changes in both the intensity of frugivory and the fruiting behavior of plants (Foster 1990b; GautierHion 1990; Terborgh 1990) may effect the structure and composition of the seed rain falling in different places in the forest, and over time in a particular forest patch. The high interpatch variability detected in the proportion of seeds coming from an immigrant origin (Table 2) may be related to such sources of seed dispersal variation.

More interesting, however, is the over-representation of tree canopy and liana species in the seed rain. Assuming similar crop sizes among trees of different heights, this pattern could be the result of more intense seed dispersal rates in the upper and mid-canopy level of the forest, where most fruit-eating arboreal mammal and bird spe- 

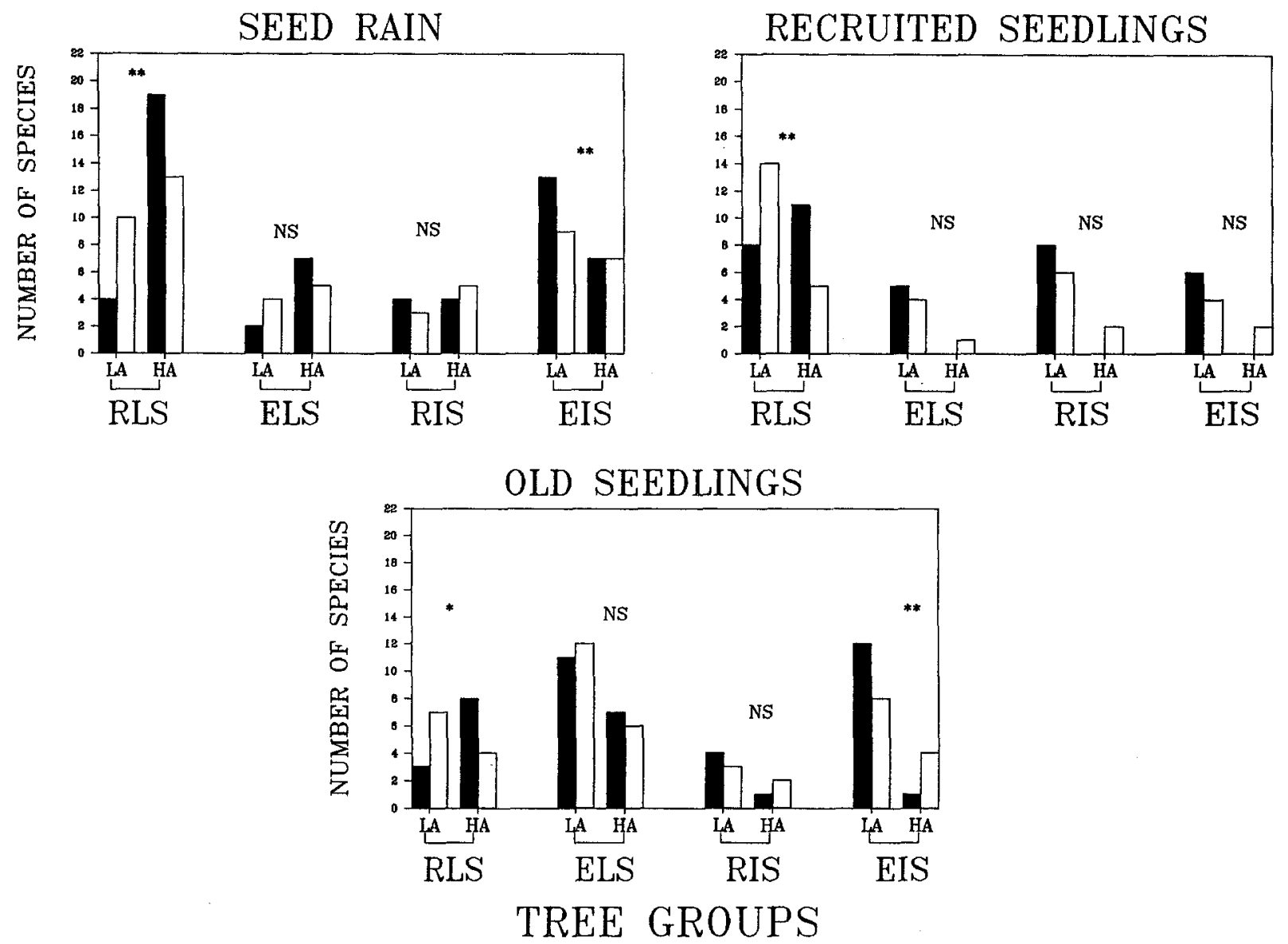

Fig. 7. Relationship between species abundance $(\mathrm{LA}=$ low abundant, $\mathrm{HA}=$ high abundant $)$ and the frequency of remaining local species (RLS), extinct local species (ELS), remaining immigrant species (RIS), and extinct immigrant species (EIS) in three life cycle-stage communities. ${ }^{* *}=P<0.01,{ }^{*}=P<0.01, N . S .=P>0.05$ based on Chi-square contingency table analysis. Observed frequencies in filled bars, expected frequencies in open bars. In cases in which expected frequencies were less than 5 , the appropriate correction to the Chi-square test was made (Sokal \& Rolf 1981). See text for further details.

cies feed (Terborgh 1986). At Los Tuxtlas, large frugivorous mammals (such as monkeys, kinkajous and porcupines) and birds (such as toucans and parrots) rarely feed in the sparsely-distributed small understory trees (R. Dirzo pers. comm.). This suggests that a lack of dispersers is one reason why low-canopy trees were under-represented in the seed rain.

An alternative explanation may be related to differences in fecundity among tree species. We can expect average fecundities to increase from understory to upper-canopy trees due to larger crown sizes and better light conditions of the latter. The few fecundity schedules available for rainforest trees seem to support this assertion
(Alvarez-Buylla \& Martínez-Ramos 1992). Even with similar seed dispersal rates in understory and canopy tree groups, the larger fruit crops of upper-canopy trees could enable a larger number of seeds to be dispersed per unit area.

Lianas, which were the most frequent species represented as immigrant seeds, have smaller stem diameters than trees (Putz 1983). This might seem to contradict the above scenario. However, the rate of increase of crown-leaf area per unit of rate of increase in stem diameter is higher in lianas than in trees, and individual lianas may have extensive leaf crowns spreading over several trees (Putz 1983). It is therefore possible that liana fruit crops may reach comparable sizes to those of 
some canopy trees. This topic deserves further study.

\section{Variability of seed rain over time and space}

At Los Tuxtlas and in other rainforest localities (Foster 1990a; Gautier-Hion 1990), lianas, canopy trees and understory species differ in their timing of fruit production. At Los Tuxtlas and Barro Colorado Island, Panama, most canopy species produce fruits in the rainy season whereas several understory species (mostly dispersed by migratory birds) fruit in winter (G. Ibarra pers. comm.; Foster 1990a). An added factor could be the differences in seed fall timing between canopy and understory trees, which could lead to temporal changes in the seed rain composition.

The abundance and spatial distribution of fruiting species must also play a role in generating diversity in the seed rain. Because most of the species are rare and/or have a clumped distribution (M. Martínez-Ramos \& E. Alvarez-Buylla, unpubl.; Hubbell \& Foster 1983), we can expect considerable variation in the species composition of the seed rain falling at different forest locations. This expectation seems to be illustrated by the fact that most immigrant seed species were recorded in only one of the five study plots (Fig. 4).

\section{Seed rain and the organization of advanced regen-} eration

With the exception of a few light-demanding trees (e.g. Ficus yoponensis, Lunania mexicana), most abundant species recorded as seeds were also present as seedlings. Even some seedlings of the gap-dependent tree Cecropia obtusifolia were encountered, presumably because of the great abundance of seed present (Fig. 3a). The light environment of the closed canopy sites studied did not limit germination and early development of most species.

In most species there was a strong numerical reduction in the transition from seed to seedling stage. Seeds experience a variety of mortality sources, including physiological disorders, predispersal predation, random events such as inhibitory germination by litter (Vázquez-Yanes et al. 1990), and post-dispersal predation or pathogen attack (Dirzo \& Dominguez 1986; Howe 1990). If these mortality factors act with the same intensity on species independently of their abundance, rare species (at an extreme, those represented by only one individual) have a higher chance of becoming locally extinct. However, frequent-independent processes did not explain the many rare, mostly immigrant, species that were found in the old-seedling and sapling communities. Poulsenia armata (Moraceae) is particularly notable in this respect. Although an unimportant species in the seed rain and seedling communities, $P$. armata was the most abundant species in the sapling community. Another similar case was Pouteria sapota (Sapotaceae) (Fig. 3). In these species, rarity was associated with positive sapling establishment probabilities. Similar results have been found for some species in other neotropical rain forests (Hubbell \& Foster 1990a).

Experimental evidence for the existence of regulatory forces operating on abundant seed and seedling populations has been documented for several species in the study plots used here (Martínez-Ramos 1991). For example, Pseudolmedia oxyphyllaria and Nectandra ambigens, two of the ten most abundant seed, seedling and sapling species in the study plots, demonstrated density-dependent changes in population numbers although through different processes. Under parent trees, seeds of $P$. oxyphyllaria are strongly preyed upon by rodents. However, the widely scattered seedlings indicate that seed dispersal may confer better survival probabilities to those seeds falling away from parent trees. This pattern is similar to that of Virola surinamensis in Panama (Howe 1990). In contrast, seeds of the uppercanopy tree $N$. ambigens suffer considerably lower seed predation than $P$. oxyphyllaria. Approximately half of the seeds falling under parent trees germinate there, forming high density populations of long-lived seedlings (see also Sarukhán 1978 and Córdova 1985); very few seedlings are found away from fruiting trees. Seed dispersal seems 
not to be important for seedling establishment (Córdova 1979), as in Tetragastris panamensis on Barro Colorado Island, Panama (Howe 1990). However, when $N$. ambigens seedling populations are crowded, mortality rates increase rapidly because of seedling competition and/or pathogen attack (Martínez-Ramos 1991). Certainly some inhibitory or regulatory mechanisms operate in seedling populations of $N$. ambigens, since this was the most abundant species in the seedling community (Fig. 3) but was poorly represented as saplings (Fig.3).

As a result of the thinning processes operating on abundant species, equitability and diversity increased in communities of late life-cycle stages. Within this trend, species that produce small seeds and PC-seedlings suffered the strongest numerical reduction, and most of them were not found at the sapling community. The increase in diversity from the seed rain to the sapling community was largely due to the elimination of these small seeded species. On the contrary, species that produce large seeds and RC-seedlings seem to have higher rates of survival and a higher probability of being represented in advanced regeneration. A higher seed and seedling mortality rate operating on the most abundant large-seeded species also helps to explain the higher diversity found in the old-seedling and sapling communities (Martínez-Ramos 1991).

In a community context, seed size and seedling morphology influence the survivorship probabilities of seedlings (Fenner 1985). Actually, these traits are correlated; species producing small seeds mostly give rise to epigeous seedlings that die at higher rates than seedlings with high maternal resources stored in specialized organs which are mainly produced by large seeded species (Ng 1978; Hladik \& Miquel 1990). Lightdemanding trees exhibit epigeous seedlings whereas most long-lived species produce large seeds that readily germinate in the shade $(\mathrm{Ng}$ 1978; Hladik \& Miquel 1991; Vázquez-Yanes \& Oroczo-Segovia 1984, 1990). High maternal resources enable seedlings to survive and grow even under reduced light conditions (Howe 1990). This is because large seeds give rise to robust seedlings
(Ng 1978; Hladik \& Miquel 1990; Howe \& Ritcher 1982) which can withstand mortality risks imposed by physical and animal injuries (Fenner 1985; Foster 1986). These processes are consistent with the observation that large seeded, persistent species form the largest part of the seedling and sapling communities in closed canopy sites. Similar patterns of seedling recruitment have been found in an African rain forest (Hladik \& Miquel 1990).

A mixture of physiological, population regulatory and random factors influence the organization of advanced regeneration. We suggest that species' biology (seed size, seedling morphology, shade-tolerance, plant-animal interactions), more than random events, organizes the community at the seedling and sapling levels in closed canopy sites.

\section{Conclusions}

Tropical rain forests are dynamic systems. From the information obtained in the present study we suggest links between the roles of gap dynamics and seed sources (local versus immigrant) in the regeneration processes of a tropical rain forest. The role of immigrant seeds may depend particularly on the type of patch where a seed lands. In forest patches with high canopy turn-over rates, such as those found along forest borders and in steep-sloped sites (Martínez-Ramos et al. 1988b), immigrant seeds will play an important role in generating within-patch diversity. In such sites, high turn-over rates do not favor the establishment of long-lived persistent trees. Therefore, advanced regeneration of these species will depend on immigrant seeds. Pioneer and late-secondary species may dominate the structure of the patches. However, because seedlings of these light-demanding trees do not establish in shade, seedlings of persistent species arriving through seed dispersal will constitute a diverse seedling community of low abundance. In fact, the patches studied found in the early successional stages have a significantly less abundant but more diverse seedling community than the patches found in the mature phase (Martínez-Ramos 1991). 
At the other extreme, in forest patches with very low canopy turn-over rates in which longlived species are established (Martínez-Ramos et al. $1988 \mathrm{~b}$ ), immigrant species will play a minor role in generating diversity. Long-lived tree species produce crops of large seeds (such as Nectandra ambigens at Los Tuxtlas) which in turn generate abundant seedling banks (Martínez-Ramos 1985). Because local species seem to have a better chance than immigrant species of recruiting into advanced regeneration, a self-regenerative pathway may predominate in these forest patches of low turn-over. As the time elapsed between disturbances increases, seedlings and saplings of local species eventually dominate advanced regeneration. When the canopy opens up, large seedlings and saplings may have competitive advantages over recently emerging seedlings in reaching a place in the canopy (Uhl et al. 1988). However, the observation that some immigrant species do get established as saplings also indicates that there may be a slow infiltration resulting in a slow shift in the species composition of advanced regeneration. In the long term this slow infiltration could lead to a floristic homogenization among forest patches.

Finally, in patches with an intermediate canopy turn-over rate we can expect a mixture of the two regeneration possibilities described above. Since rain forests are in reality shifting mosaics of vegetation patches, each one with a different disturbance history, the relative contribution of local and immigrant species to the seed rain community will change temporally and spatially. As this study suggests, understanding the role played by seed rain in community organization can be reached through an integrative approach, by studying the processes and mechanisms that govern the fate of seed populations as they advance from one lifecycle stage to the next.

\section{Acknowledgements}

This paper was possible through the generous assistance of many people. We particularly thank Santiago Sinaca who helped us with the identifi- cation of seeds and seedlings and to George Dyer, Teresa Hernández, Graciela García, Mario González, Steve Littman, Paulina Parlange, Eduardo Rincón-Gallardo, Maricruz Rosas, Jorge Rodríguez, and Saúl Segura whom worked with us in the field and/or in the laboratory. We thank the staff of Los Tuxtlas Tropical Field Station, Instituto de Biología, UNAM, for all the facilities provided. The manuscript was improved by helpful comments made by Elena Alvarez-Buylla, Fahkri Bazzaz Ted Fleming, Jim Hamrick, Collin C. Kelly, and Eugene Schupp. The project was supported by a grant from Consejo Nacional de Ciencia y Tecnologia of México. The final version of the manuscript was completed while MMR was a Bullard fellow in the Department of Organismic and Evolutionary Biology, Harvard University.

\section{References}

Alvarez-Buylla, E. \& Martínez-Ramos, M; 1992. Demography and allometry of Cecropia obtusifolia, a neotropical pioneer tree - an evaluation of the climax - pioneer paradigm for tropical rain forests. J. Ecology 80: 275-290.

Augspurger, C. K. 1984. Seedling survival of tropical tree species: interactions of dispersal distance, light gaps, and pathogens. Ecology 65: 1705-1712.

Bongers, F., Popma, J., Meave, J. \& Carabias, J. 1988. Structure and floristic composition of the lowland rain forest of Los Tuxtlas, Mexico. Vegetatio 74: 55-88.

Brokaw, N. V. L. 1985. Gap phase regeneration in a tropical forest. Ecology 66: 682-687.

Chazdon, L. R. 1988. Sunflecks and their importance to forest understory plants. Adv. Ecol. Res. 18: 1-63.

Clark, D. \& Clark, D. 1984. Spacing dynamics of a tropical rain forest tree: evaluation of the Janzen-Connell model. Amer. Nat. 142: 769-788.

Clark, D. B. \& Clark, D. A. 1989. The role of physical damage in the seedling portality of a neotropical rain forest. Oikos 55: 225-230.

Connell, J. H., Tracey, J. G. \& Webb, L. J. 1984. Compensatory recruitment, growth, and mortality as factors maintaining rain forest tree diversity. Ecological Monographs 54: $141-164$.

Córdova, B. 1979. Efectos de la densidad, la distancia al árbol y la depredación en el crecimiento y sobrevivencia de plántulas de Nectandra ambigens (Blake). Tesis de Profesional. Facultad de Ciencias, UNAM, México.

Córdova, B. 1985. Demografia de árboles tropicales. In: Gómez-Pompa, A. S. \& Del Amo, S. (eds). Investigaciones 
sobre la regeneración de selvas altas en Veracruz, México Vol II. pp. 103-128. INIREB, Alhambra, México.

Denslow, J. 1987. Tropical rain forest gaps and tree species diversity. Ann. Rev. Syst. Ecol. 18: 432-451.

Dirzo, R. 1987. Estudios sobre interacciones planta-herbivoro en 'Los Tuxtlas', Veracruz. Rev. Biol. Trop. (Supl. 1) 35 : 119-132.

Dirzo, R. \& Dominquez, A. C. 1986. Seed shadows, seed predation and the advantages of dispersal. In: Estrada, A. \& Fleming, T. H. (eds). Frugivores and seed dispersal. pp. 237-249. Dr. Junk Publishers, The Hague, the Netherlands.

Dirzo, R. \& Miranda, A. 1991. Altered patterns of herbivory and diversity in the forest understory: a case study of the possible consequences of contemporary defaunation. In: Price, W. P., Lewinson, M., Wilson, G. \& Woodruff, W. B. (eds). Plant-animal interactions: evolutionary ecology in tropical and temperate regions. pp. 273-447. John Wiley and Sons, Inc, USA.

Fenner, M. 1985. Seed ecology. Chapman and Hall. New York, USA.

Foster, S. A. 1986. On the adaptative value of large seeds for tropical moist forest trees: a review and synthesis. The Botanical Review 52: 269-299.

Foster, R. B. 1990a. Ciclo estaconal de caída de frutos en la isla de Barro Colorado. In: Leigh, E. G., Jr., Stanley, R. A. \& Windsor, D. M. (eds). Ecología de un bosque tropical: ciclos estacionales y cambios a largo plazo. pp. 219-241. Smithsonian Tropical Research Institute, Panama.

Foster, R. B. 1990b. Hambruna en la Isla de Barro Colorado. In: Leigh, E. G., Jr., Stanley, R. A. \& Windsor, D. M. (eds). Ecología de un bosque tropical: ciclos estacionales y cambios a largo plazo. pp. 271-283. Smithsonian Tropical Research Institute, Panama.

Gauthier-Hion, A. 1990. Interactions among fruit and vertebrate fruit-eaters in an African tropical rain forest. In: Bawa, S. \& Hadley, M. (eds). Reproductive ecology of tropical forest plants. Man and the Biosphere Series. pp. 219-230. The Parthenon Pub. Group, Paris. France.

Gómez-Pomps, A. \& Del Amo S. 1985. Investigaciones sobre la regeneración de selvas altas en Veracruz, México Vol. II. INIREB, Alhambra, México.

Greig-Smith, P. 1983. Quantitative plant ecology. Studies in ecology Vol. 9. Univ. Calif. Press, L. A., USA.

Hladik, A. \& Miquel, S. 1990. Seedling types and plant establishment in an African rain forest. In: Bawa, K. S. \& Handley, M. (eds). Reproductive ecology of tropical forest plants. Man and the Biosphere Series. pp. 191-218. The Parthenon Pub. Group, Paris, France.

Howe, H. F. 1990. Seed dispersal by birds and mammals: implications for seedling demography. In: Bawa, K. S. \& Handley, M. (eds). Reproductive ecology of tropical forest plants. Man and the Biosphere Series. pp. 261-282. The Parthenon Pub. Group, Paris, France.

Howe, H. F. \& Ritcher, W. M. 1982. Effects of seed size on seedling size in Virola surinamensis; a within and between tree analysis. Oecologia 53: 347-351.

Hubbell, S. P. \& Foster, R. B. 1983. Diversity of canopy trees in a neotropical forest and implications for conservation. In: Sutton, S. L., Whitmore, T. C. \& Chadwik, A. C. (eds). Tropical rain forest ecology and management. pp. 25-41. Blackwell Scientific Publications, Oxford, UK.

Hubbell, S. P. \& Foster, R. B. 1986. Biology, chance and history and the structure of tropical rain forest tree communities. In: Diamond, J., Case, T. J. (eds). Community Ecology. pp. 314-329. Harper \& Row Publications. New York, USA.

Hubbell, S. P. \& Foster, R. B. 1990a. The fate of juvinile trees in a neotropical forest: implications for the natural maintenance of tropical tree diversity. In: Bawa, K. S. \& Handley, M. (eds). Reproductive ecology of tropical forest plants. Man and the Biosphere Series. pp. 317-344. The Parthenon Pub. Group, Paris, France.

Hubbell, S. P. \& Foster, R. B. 1990b. Structure, dynamics, and equilibrium status of old-growth forest on Barro Colorado Island. In: Gentry, A. H. (ed). Four neotropical rainforests. pp. 522-541. Yale University Press, New Haven, USA.

Ibarra, G. \& Sinaca-Colín, S. 1987. Listados florísticos de México VII. Estacíon de Biología Tropical Los Tuxtlas. Inst. Biol. UNAM.

MacCullagh, P. \& Nelder, J. A. 1983. Generalized linear models. Chapman \& Hall, London, UK.

Martínez-Ramos, M. 1985. Claros, ciclos vitales de los árboles tropicales y la regeneracion natural de las selvas altas perennifolias. In: Gómez-Pompa, A. \& Del Amo, S. 1985 (eds). Investigaciones sobre la regeneración de selvas altas en Veracruz, México Vol II. pp. 191-239. INIREB, Alhambra, México.

Martínez-Ramos, M., Alvarez-Buylla, E., Sarukhán, J. \& Piñero, D. 1988a. Treefall age determination and gap dynamics in a tropical rain forest. J. Ecol. 76: 700-716.

Martínez-Ramos, M., Sarukhán, J. \& Piñero, D. 1988b. The demography of trees in the context of forest gap dynamics: the case of Astrocaryum mexicanum at Los Tuxtlas tropical rain forest. In: Davy, D. J., Hutchings, M. J. \& Watkinson, A. R. (eds). Plant population ecology. pp. 293-313.. Blackwell, Oxford, U. K.

Martínez-Ramos, M. 1991. Patrones, procesos y mecanismos en la comunidad de plántulas de una selva húmeda neotropical. Tesis doctoral, UNAM, México.

Ng, F. S. P. 1978. Strategies of establishment in Malayan forest trees. In: Tomlinson, P. B. \& Zimmerman, H. (eds). Tropical Trees and Living Systems. pp. 129-162. Cambridge Univ. Press. Cambridge, USA.

Oldeman, A. A. R. \& van Dijck, J. 1991. Diagnosis of the temperament of tropical forest trees. In: Gómez-Pompa, A., Whitmore, T. C. \& Handley, M. (eds). Rain forest regeneration and management. Man and the biosphere series. pp. 21-65. The parthenon Pub. Group. Paris, France.

Pearcy, W. R. 1990. Sunflecks and photosynthesis in plant 
canopies. Ann. Rev. Plant Physiol. Plant Mol. Biol. pp. 421-453.

Popma, J., Bongers, F., Martínez-Ramos, M. \& Veneklaas, E. 1988. Pioneer species distribution in treefall gaps in neotropical rainforest: a gap definition and its consequences. $J$. Trop. Ecol. 4: 77-88.

Primack, R. B. 1990. Seed physiology, seed germination and seedling ecology. In: Bawa, K. S. \& Handley, M. (eds). Reproductive ecology of tropical forest plants. Man and the Biosphere Series. pp. 233-236. The Parthenon Pub. Group, Paris, France.

Putz, F. E. 1983. Liana biomass and leaf area of a tierra firme' forest in the Rio Negro Basin, Venezuela. Biotropica 15: 185-189.

Raich, W. J. \& Christensen, L. N. 1989. Malaysian dipterocarp forest: tree seedling and sapling species composition and small-scale disturbance patterns. Nat. Geog. Res. 5: $348-363$.

Sarukhán, J. 1978. Studies on the demography of tropical trees. In: Tomlinson, P. B. \& Zimmerman, H. (eds). Tropical trees as living systems. pp. 163-184. Cambridge Univ. Press., Cambridge, USA.

Sarukhán, J., Martínez-Ramos, M. \& Piñero, D. 1984. The analysis of demographic variability at the individual level and ist population consequences. In: Dirzo, R. \& Sarukhán, J. (eds). Perspectives on plant population ecology. pp. 141165. Sinauer Ass. Inc., Sunderland Mass., USA.

Sarukhán, J., Piñero, D. \& Martínez-Ramos, M. 1985. Plant demography: a community level interpretation. In: White, J. (ed). Studies in plant demography: a festschrift for John L. Harper. pp. 17-31. Acad. Press., London, UK.

Schupp, E. W. 1988a. Seed and early seedling predation in the forest understory and in treefall gaps. Oikos 51: 525-530.
Schupp, E. W. 1988b. Factors affecting post-dispersal seed survival in a tropical forest. Oecologia (Berlin) 76: 525-530.

Sokal, R. \& Rohlf, R. 1981. Biometry. W. H. Freeman \& Co. NY USA.

Terborgh, J. 1986. Community aspects of frugivores in tropical forests. In: Estrada, A. \& Fleming, T. H. (eds). Frugivores and seed dispersal. pp. 371-384. Dr. Junk Publish., The Hague, Netherlands.

Terborgh, J. 1990. Seed and fruit dispersal-commentary. In: Bawa, K. S. \& Handley, M. (eds). Reproductive ecology of tropical forest plants. Man and the Biosphere Series. pp. 181-190. The Parthenon Pub. Group, Paris, France.

Uhl, C., Clark, K., Dezzeo, N. \& Maquirino, P. 1988. Vegetation dynamics in Amazonian treefall gaps. Ecology 69: $751-763$.

Vázquez-Yanes, C. \& Orozco-Segovia, A. 1984. Ecophysiology of seed germination in tropical humid forests of the world: a review. In: Medina, E., Mooney, H. A. \& Vázquez-Yanes, C. (eds). Physiological ecology of plants of the wet tropics. pp. 37-49. Dr. Junk Publishers, The Hague, the Netherlands

Vázquez-Yanes, C. \& Orozco-Segovia, A. 1990. Seed dormancy in the tropical rain forest. In: Bawa, K. S. \& Handley, M. (eds). Reproductive ecology of tropical forest plants. Man and the Biosphere Series. pp. 233-236. The Parthenon Pub. Group, Paris, France.

Vázquez-Yanes, C., Orozco-Segovia, A., Rincón, E., Sánchez-Coronado, M. E., Huante, P., Barradas, V. \& Toledo, J. R. 1990. Light beneath the litter in a tropical forest: effect on seed germination. Ecology 71: 1952-1958.

Whitmore, T. C. 1989. Canopy gaps and two major groups of forest trees. Ecology 70: 536-538. 